EXTEDUCATION/O,content.

World Bank. (2013b). Africa overview. Retrieved on August 30, 2013, from http://www.worldbank.org/en/region/afr/overview.

World Bank. (20I3c). New ways to finance development in Sub-Saharan Africa. Retrieved on October I4, 20I3, from http:econ.worldbank. org/WBSITE/EXTERNAL/EXTDEC/O,contentMDK:2I6785Io-p.

World Bank. (2013d). As Africa's new wealth grows, poverty must come down. News. Retrieved on October 29, 2013, from http://www. worldbank.org/en/news/feature/2013/04/15/as-africa-s-n.

\section{The Regionalisation, Internationalisation, and Globalisation of African Higher Education}

\author{
Chika Sehoole and Hans de Wit
}

\section{Abstract}

The landscape of international higher education has been changing since the turn of the 2Ist century. The globalisation of our societies and economies implies a changing role of the higher education institutions. Accompanying the challenges associated with development, especially in developing countries, are initiatives championing regionalisation as a locus of development. This article positions the debate on the relationships among globalisation, regionalisation, and internationalisation in the context of Africa and its sub-continent, showing that, although these concepts have emerged at different times and contexts, they are still related. Using case studies of two regional political and economic organisations and their higher education counterparts, this article shows that regionalisation is not a new phenomenon but has been part of and has been used in the post-colonial era to serve new social, economic, political, and development purposes in the current period.

about the authors: chika sehoole is an Associate Professor and Head of the Department of Education Management and Policy Studies at the University of Pretoria, South Africa. He holds a PhD from the University of the Witwatersrand, Johannesburg. He is the current chair of the Board of the African Network for the Internationalisation of Education (ANIE). Address queries to him at Chika. Sehoole@up.ac.za. HANS DE wIT is director of the Centre for Higher Education Internationalisation at the Università Cattolica del Sacro Cuore in Milan, Italy, and professor of the Internationalisation of Higher Education at the Amsterdam University of Applied Sciences in the Netherlands. He is Founding Editor of the Journal of Studies in International Education and Co-Editor of the SAGE Handbook on International Higher Education. He is a Research Associate at the Nelson Mandela Metropolitan University in Port Elizabeth, South Africa. Address queries to him at j.w.m.de.wit@hva.nl. Both authors were Fulbright Scholars in the New Century Scholarship Programme, Higher Education in the 2Ist Century, 2005-2006. 
Le monde de l'enseignement supérieur n'a cessé de changer depuis le début du XXIème siècle. La mondialisation de nos sociétés et de nos économies a pour conséquence une modification du rôle joué par les établissements d'enseignement supérieur. Les défis posés par cette évolution sont, en particulier dans les pays en voie de développement, associés à des initiatives soutenant la régionalisation comme locus de développement. Cet article centre le débat sur la relation entre la mondialisation, la régionalisation et l'internationalisation dans le contexte de l'Afrique et de son sous-continent, et démontre que, bien que ces concepts soient apparus à différentes époques et dans des contextes variés, ils sont encore liés. Cet article s'appuie sur une étude de cas de deux organisations régionales politiques et économiques et de leurs équivalents dans le domaine de l'enseignement supérieur pour montrer que le concept de régionalisation n'est pas un phénomène nouveau, mais qu'il a fait partie de et a été utilisé pendant l'époque postcoloniale pour satisfaire de nouveaux objectifs sociaux, économiques, politiques et de développement.

\section{Introduction}

In this article, we position the debate on the relationships among globalisation, regionalisation, and internationalisation in the context of Africa and its sub-continent, showing that, although these concepts have emerged at different times and contexts, they are still related. Regionalisation as a sub-set of internationalisation contributes to giving expression both to internationalisation and also to globalisation. This phenomenon has been studied more for developed countries, in particular the European unification process. Accompanying the challenges associated with development, especially in developing countries, are initiatives championing regionalisation as a locus of development. Higher education is assigned an important role in regional development initiatives (Kotecha, 20I2; Zeleza, 20I2). Unlike globalisation perspectives that mainly champion economic rationales for development, this article makes a case for the social, political, and human development role for higher education in regional development. We present two case studies from Southern and Eastern Africa in support of this perspective. In tracing the historical evolution of these regional organisations, we demonstrate that regionalisation is not a recent phenomenon but has been used to meet new social, economic, political, and development purposes in challenges that have emerged since independence. The evolution of these regional organisations in the political and economic spheres have been mirrored by the development of regional higher education organisations that play an important role in knowledge production, capacity building, and fulfilment of the socio-political and economic development needs of their regions. However, the developmental role of these organisations in regional development is not without challenges, a fact that our article scrutinizes.

\section{The Changing Landscape of Internationalisation}

The landscape of international higher education has been changing since the turn of the 2Ist century (de Wit, 2002; Shabani, 20I0; Teferra \& Knight, 2008; Zeleza, 20I2). The international dimension and the role of higher education in the global arena are more dominant in international, national, and institutional documents and mission statements than ever. The increasing importance of knowledge and its production-indeed, the very notion of the "global knowledge economy"-implies not only increased research but also teaching, learning, their cross-border delivery, and the creation of new forms of cooperation and competition. At the same time, higher education in emerging and developing countries and regions is gradually shifting from a reactive and "Western"-copied and -dominated system into a more proactive and independent sector of public and private universities. This change challenges traditional Western dominance and its style of assumptions about how to deal with the internationalisation of higher education. Although the world rankings of higher education institutions do not make this pattern manifest and several counteracting developments will hinder a rapid change in this direction, some positive signs include the increasing strength of higher education in emerging countries and increasing South-South cooperation, in particular in these countries.

As Eva Egron-Polak (20I3), the Secretary General of the International Association of Universities (IAU), formulates it:

Just as the scope and complexity of the challenges facing humanity are unprecedented, so are the opportunities to address them. Higher education and research institutions are central to finding solutions and to creating greater awareness among students and the larger public about numerous global issues. Since most of these challenges are intrinsically linked to the globalised nature of our world, internationalisation-defined in the simplest but perhaps the most comprehensive manner as an appreciative openness to the world and to other ways of knowing and learning-is an essential dimension of higher education and of the search for truth and knowledge in this more globalised context. It can also become an essential pathway to a more inclusive global higher education space of our making. (p. 90) 
Many scholars including Scott (2005), Altbach (2006), Van Vught, van der Wende, and Westerheijden (2002), and Knight (2008), address the complex relationship between globalisation and the internationalisation of higher education. According to Scott (2005), "The distinction between internationalisation and globalisation, although suggestive, cannot be regarded as categorical. They overlap, and are intertwined, in all kinds of ways" (p. I4).

Altbach (2006) defines globalisation as

the broad economic, technological, and scientific trends that directly affect higher education and are largely inevitable in the contemporary world [while internationalisation] . . . refers to specific policies and programmes undertaken by governments, academic systems and institutions, and even individual departments to support student or faculty exchanges, encourage collaborative research overseas, set up joint teaching programs in other countries or a myriad of initiatives. (p. I23)

Van Vught, van der Wende, and Westerheijden (2002) state:

In terms of both practice and perceptions, internationalisation is closer to the well-established tradition of international cooperation and mobility and to the core values of quality and excellence, whereas globalisation refers more to competition, pushing the concept of higher education as a tradable commodity and challenging the concept of higher education as a public good. (p. I7)

For Knight (2008),

globalisation is the process that is increasing the flow of people, culture, ideas, values, knowledge, technology, and economy across borders, resulting in a more interconnected and interdependent world. Globalisation affects each country in different ways and can have positive and/or negative consequences, according to a nation's specific history, traditions, culture, priorities, and resources. Education is one of the sectors impacted by globalisation. (pp. x-xi)

Internationalisation for Knight is "the process of integrating an international, intercultural or global dimension into the purpose, functions or delivery of post-secondary education," (p. iI) a definition of internationalisation that is widely accepted

Even though different accents are made by these and other authors, one can say that globalisation is a social, economic, and political process to which higher education responds and in which it is an actor itself, and internationalisation is the way higher education responds to and acts in it.

\section{Globalisation, Internationalisation, and Regionalisation}

Along with globalisation and internationalisation has come a growing awareness of the importance of regional cooperation as seen in the European Union (EU), the North American Free Trade Agreement (NAFTA), the Asia Pacific Economic Cooperation (APEC), Mercado Comun del Sur (MERCOSUR), the Association of South East Asian Nations (ASEAN), and many other regional and sub-regional initiatives. Among them, greater trade interdependencies have been recognised in three regions, namely, the EU, NAFTA, and Japan with other East Asian countries (Tsuruta, 2003). On the African continent, the emergence of the Southern African Development Community (SADC), the Economic Community of West African Societies (ECOWAS), and the East African Community (EAC) to name just a few, are further manifestations of the growing importance of cooperation among nation states at a regional level. In particular, regionalisation on the continent has been driven through the formation of policy development bodies like the New Partnership for Africa's Development (NEPAD), the Association of African Universities (AAU), the Association for the Development of Education in Africa (ADEA), the Inter University Council for Eastern Africa (IUCEA), the Southern African Regional Universities Association (SARUA), and the African Virtual University (AVU). All of these organisations seek common strategies to address educational challenges in Africa particularly in access, equity, capacity building, and quality assurance.

An anticipated result of regional integration in higher education is the enhancement of both student and staff mobility across institutions within the region and on the continent in general. Other results are the harmonisation of policy and guidelines for quality assurance and the evaluation of qualifications across institutions in order to facilitate equivalency, comparability, and transferability of credit across countries. As policy documents from different parts of the world indicate (see, for instance, the communiqué of the European Commission, "European Higher Education in the World," 20I3), internationalisation, regionalisation, and globalisation are key factors that shape higher education and research strategies and give rise to both cooperation and competition. The development of regional education and research areas in various parts of the world challenges national values and cultures and calls for new regional instruments that address, for example, quality assurance and recognition.

These perspectives on regionalisation point to the way in which different parts of the world are dealing with the reality of this phenomenon. According to Mhlanga (2012) regionalisation refers to the grouping of nations within a common geographical location in order to strengthen cooperation and sharing as a strategy for achieving development. Such 
groupings are motivated by physical and cultural proximity as well as by common challenges. The process of regionalisation gives institutions an international character.

Knight (2013) views regionalisation as an intentional process, which differentiates three interrelated approaches-the functional approach, the organisational approach, and the political approach.

The first approach takes a functional perspective of regionalisation and focuses on the practical activities of higher education institutions and systems. Functional approach initiatives can be put into two distinct groups. The first group describes strategies that facilitate closer alignment or, in some cases, harmonisation among national/sub-regional higher education systems. The second category includes programmes like student mobility schemes, cross-border collaborative education programmes, pan-regional universities, and centres of excellence. The relationship between these two groups is critical as the systems/policies in the first group are needed to facilitate and expedite the programmes in the second. For instance, compatibility among quality assurance systems and academic credit systems will help student mobility programmes within a region.

The second approach refers to the organisational architecture that evolves to develop and guide regionalisation initiatives in a more systematic (although some might call it "bureaucratic") manner. It is labelled an organisational approach because frameworks, structures, and agencies are necessary to help establish and oversee regional-level and intra-regional initiatives. A diversity of networks and organisations are emerging which include government and non-government bodies, professional organisations, foundations, and networks. These entities assume a variety of responsibilities-policymaking, funding, research, capacity building, regulation, and advocacy among others.

The third approach involves political will and strategies that put higher education initiatives on the agenda of decision-making bodies. The political approach helps to launch major programmes or funding schemes and to formalize initiatives. Declarations of intent, binding conventions, treaties, protocols, agreements, and special meetings like summits or policy dialogues are instruments for generating political support and visibility in order to make regionalisation of higher education a priority. This approach can be characterised as having more of a top-down, formal, and intentional orientation.

The foregoing discussion highlights the relationship (and some overlaps) between globalisation, internationalisation, and regionalisation. While internationalisation and regionalisation have been part of the evolution of inter-state and regional cooperation for many years, globalisation is a fairly new phenomenon that gained prominence at the turn of the 2ist century. Globalisation has changed the way internationalisation and regionalisation function in the current situation. We next focus on the evolution of regionalisation in Africa, highlighting the fact that regionalisation has been part of Africa's struggle for liberation and the subsequent attainment of self-determination and development.

\section{Regionalisation in Africa}

The term "region" in Africa is varied and complex, expressed in different forms and involving multiple players. The working definition of regionalisation adopted in our discussion is conceptualised as a subset of internationalisation. Zeleza (20I2) points out that internationalisation processes and subactivities are mediated through and involve six sets of actors: international actors, bilateral actors, interregional actors, regional actors, subregional actors, and national actors. It is important to note three levels of regionalisation that express internationalisation: interregional, regional, and subregional.

The leading interregional actors for Africa comprise government agencies such as the European Commission and interregional nongovernmental organisations and networks such as the European University Association, the Association of Commonwealth Universities, and the Association of Universities of the Francophone. Regional actors range from intergovernmental bodies such as the African Development Bank and the African Union to regional non-governmental organisations such as the Association of African Universities and the Council for the Development of Social Science Research in Africa, while sub-regional actors include organisations such as the Southern African Regional Universities Association (SARUA) and the Inter University Council for East Africa (IUCEA) (Zeleza, 20I2). The concept of "region" can also be used to describe geographic areas or communities such as Southern Africa, East Africa, West Africa, and North Africa. Other terms used to describe "region" are drawn from culture or language, such as Francophone Africa, Arabophone Africa, or Lusophone Africa.

This article uses "region" as expressed at the sub-regional level. Africa has varied and distinct regions that provide interesting perspectives of regionalisation. We argue that the patterns of regionalisation of higher education at the sub-regional level mirror the organisational architecture of regionalisation in the political and economic spheres as finding expression in sub-regional levels. Two examples provide the case studies for this article. 


\section{Regionalisation in Southern Africa: SADC and SARUA}

In Southern Africa, the project of regionalisation has undergone several metamorphoses. Starting as an apartheid project during colonialism, this political project was aimed at integrating the region into a wider Southern African economy. This result was to be achieved by creating a constellation of states within the region that would promote, support, and consolidate colonial interests. As more states became politically independent within the region, they reconceptualised the concept through the formation of the Southern African Development Co-ordination Committee (SADCC). This entity was a regional diplomatic coalition of independent Southern African Front-line States consisting of Angola, Botswana, Mozambique, Tanzania, Zambia, and Zimbabwe. In character, the Front-line States represented a unique idiosyncratic diplomatic alliance fully committed to the anti-apartheid cause and the South African liberation movements.

The Southern African Regional Community (SADC) originated in the I960s and I970s when the leaders of majority-ruled countries and national liberation movements coordinated their political, diplomatic, and military struggles to end colonial and white-minority rule in Southern Africa. The Front-line States sought equilibrium while dealing with South African counter-revolutions and represent a loose coalition bound by common perceptions and beliefs concerning regional liberation and Africanist ideology (Evans, I984, p. 7). Key drivers of regional cooperation were not economic; rather, they took the form of diplomatic alliances, security concerns, the quest to end colonialism, and the pursuit of national liberation. Even though there was international solidarity in the form of support from countries such as the then-Union of Soviet Socialist Republics (USSR), Cuba, China, and the broader anti-apartheid movement in the Western countries, the struggle for liberation was motivated by regional concerns in both form and content. In its new post-2000 format, SADC aims to further socio-economic cooperation and integration as well as political and security cooperation among I5 southern African states. SADC complements the role of the African Union.

Following the attainment of freedom and the independence of all SADC countries has come a growing emphasis on an economic agenda with the initiation of the SADC Free Trade Area in 2000 to facilitate trade cooperation among member states. In 2008, SADC joined with the Common Market for Eastern and Southern Africa (COMESA) and the East African Community to form the African Free Trade Zone, including all members of each of these three organisations. The African Free Trade Zone aims to strengthen the bloc's bargaining power when negotiating international deals. The creation of regional free trade is part of the emergence of globalisation, sharing its aim of creating a single trade regime like that expressed through the World Trade Organisation. Regional organisations on the African continent form part of this global phenomenon, underscoring the view that globalisation not only happens with the agreement of nation states, but also with the cooperation and support of regional organisations.

Political and economic motivations have traditionally played a strong role in integration in Africa, but since the turn of the 2Ist century has come an increased emphasis on the social dimensions (Kotecha, 20I2). By 200I, regional economic communities had begun to clearly articulate the link between regional integration and social and economic development, as evidenced by the newly established African Union's adoption of the New Partnership for Africa's Development (NEPAD). Along with the development of regional political and economic blocs, regional higher education bodies have emerged, mirroring parent bodies in the political and economic spheres.

For example, in 2005, the I5 SADC countries established the Southern African Regional University Association (SARUA), a not-for-profit leadership association of the heads of those countries' public universities (SARUA, 20I2), with a mission to promote, strengthen, and increase higher education, research, and innovation through expanded interinstitutional collaboration and capacity-building initiatives throughout the region. Currently, SARUA has $\sigma_{3}$ affiliated universities.

The relationship between regional political and economic organisations and higher education institutions is a global phenomenon. As Teferra (2008) points out, "universities, as sole knowledge gateways in much of the world, are being revitalised, retooled, and reconfigured strategically to address national agendas with an international dimension" (p. 557).

More than ever before, knowledge holds a central position in the socio-economic development of nations and regions. Countries and regions are striving to ensure that knowledge domains are effectively mobilised, not only for economic success but also to enhance global competitiveness. Universities and other higher education institutions are assigned a central role in this quest.

The mission of SARUA as outlined above highlights important elements of cooperation and collaboration in the region. Its aim is not a movement toward homogeneity but toward an acknowledgement of diversity. This value is important given the diversities of languages, cultures, and levels of development that exist within the region. For example, apart from the many national and ethnic languages spoken 
within its nation states, the I5 SADC member states can also be classified into three linguistic groups based on their colonial histories. The Anglophone countries are South Africa, Zimbabwe, Botswana, Lesotho, Swaziland, Malawi, Tanzania, and Zambia. Francophone countries are Democratic Republic of Congo, Mauritius, Seychelles, and Madagascar. Lusophone countries are Angola and Mozambique. Namibia has a heritage of Afrikaans and German. SADC uses three official languages (English, French, and Portuguese)—constituting another challenge for independent African nations. Despite these differences, these countries share commonalities which include the legacy of colonialism and therefore similar challenges of development; many of them supported each other in their struggles to end colonial and white minority rule. They share a common geographic space on the southern part of the continent; many have a heritage of natural resources which are extracted and exploited by multinational companies to the detriment of these countries; and their higher education systems typically mirror those of their former colonisers in the metropoles. The commonalities and heritage which these countries share-and the challenges of exploitation and development which they face-provide a strong rationale for cooperation, coordination, and development at the regional level beyond the nation state. They also provide a basis for developing perspectives of regionalisation and internationalisation that are rooted within the history and contexts of the evolution of these countries.

\section{Regionalisation in East Africa: The Cases of EAC and IUCEA}

The East African Community (EAC) is the regional intergovernmental organisation of the Republics of Burundi, Kenya, Rwanda, Tanzania, and Uganda with its headquarters in Arusha, Tanzania. The EAC aims at widening and deepening cooperation among the partner states and other regional economic communities in, among others, political, economic, and social fields for their mutual benefit. The original founder-members of this community (Kenya, Tanzania, and Uganda) have a history of cooperation dating back to the early 2oth century. The customs union between Kenya and Uganda in I9I7, which thenTanganyika joined in I927, was followed by the East African High Commission (I948-196r), the East African Common Services Organisation (196I-I967), and the East African Community (I967-1977). Economic rationales seem to have dominated cooperation among participating countries. Following these countries' independence in the I960s, integrated activities were reconstituted by the successor organisations named above. Following the collapse of the East African
Community in I977, it was reestablished under the same name in 2000. Since then, a customs union and a common system of tariffs have been established (Kamala, 2006).

The Inter University Council of East Africa (IUCEA) is a regional higher education body that coordinates higher education in East Africa. This organisation has its roots in the pre-independence era when Makerere University College was the only higher education institution in the region, serving students from Kenya, Tanganyika, and Zanzibar in East Africa and from Malawi, Zambia, and Zimbabwe in Southern Africa. In I970, the University of East Africa was dissolved and the University of Dar es Salaam, Makerere University, and the University of Nairobi were established as separate national universities for Tanzania, Uganda, and Kenya respectively. Also in I970, the Inter-University Committee (IUC) was established to facilitate contact and cooperation among these three universities under the auspices of the first East African Community (EAC).

Upon its reestablishment, EAC recognised IUCEA as one of the surviving institutions of the former community. In 2009 the East African Legislative Assembly passed the IUCEA Act, effectively integrating IUCEA into the EAC operational framework. Thus, unlike SARUA, which has enjoyed political support and an official relationship with SADC but without financial support, IUCEA has organisational, politi$\mathrm{cal}$, and financial support from EAC, its regional political and economic body. (See http://www.iucea.org/.)

Up to this point, this article has discussed developments at the regional level in the Southern and East African subcontinent. They have shown how cooperation has been part and parcel of these regions both in the colonial and post-colonial eras. Different rationales including political, economic, military, and educational factors have driven and informed cooperation, producing some overlaps between the forms and expressions of regionalisation and those of globalisation and internationalisation. Economic cooperation and integration in the two regions have resulted in the establishment of COMESA, with a rationale driving the quest to establish a global free-trade regime, mirroring the goal of the World Trade Organisation. A further overlap occurs in the principles informing regional cooperation among nation states and the resulting expression of that form of internationalisation.

The two regional bodies, SADC and EAC, would not have come into existence without the cooperation of national governments. Once established, they have become the means and agents through which the internationalisation phenomenon also finds expression. For example, in the study of academic mobility in higher education 
as a phenomenon of internationalisation, the SADC region features prominently as a region with the most mobile students second only to Europe (UNESCO, 20I2). The same data used in the study of the phenomenon of internationalisation are also relevant for the study of regionalisation. While regionalisation depends on the voluntary cooperation of national governments in the region, internationalisation depends on the cooperation of national governments and/or regional bodies to succeed. Similarly, globalisation also requires, among other factors, the cooperation of regional organisations to attain its objectives.

The process of regionalisation is complex and not without its own challenges. As Kotecha (20I2) points out, regional integration is a complex process and the desired developmental outcomes are by no means automatic, particularly when trade creation and diversification are the key drivers of the process. Within Southern Africa, an ambitious timeline for trade integration was laid out in SADC's Regional Indicative Strategic Development Plan; but as of 20IO, the free trade area (set for 2008) had not been fully implemented and the goal of establishing a customs union by 2010 had not been met (TRALAC, 20II). The suitability of a linear model of regional integration for addressing development challenges in the southern African region has been questioned, given its central focus on trade in goods and negotiating trade tariffs rather than dealing with the "real challenges to regional integration which lie behind the border" (TRALAC, 20II, p. 2). These challenges include infrastructure deficits, poor regulatory regimes, and high-cost and inefficient services. Some of the challenges of regional integration include anti-immigrant attitudes. One study found that "citizens across the region consistently tend to exaggerate the numbers of non-citizens in their countries, to view the migration of people within the region as a 'problem' rather than an opportunity, and to scapegoat noncitizens" (Crush \& Pendleton, 2007, pp. 64-89).

The intensity of these feelings varies significantly from country to country. From a political perspective, Kornegay (2006) argues that the "real, if limited, sense of being part of a common political space and of holding common political values in southern Africa ... is shared more by governments, and in particular heads of state and government, rather than by the average person" (p. 6). These challenges point to the limitations of state-led regional integration. As Kotecha (20I2) points out, the regional integration process should involve both government and civil society. Furthermore, regional identity and citizenship must be developed from the bottom up, rather than imposed from above, if it is to have meaning in the lives of ordinary Southern Africans and earn their support. This approach requires the active involvement of a range of civil society actors, including universities.

Underlying development in regionalisation, internationalisation, and globalisation is the role of higher education, which must produce the knowledge, human resources, and skills to sustain such developments. The higher education regional bodies discussed above have been assigned important roles, which include contributing to meeting national and regional developmental needs (IUCEA), promoting universities as major contributors toward building knowledge economies, and investing national and regional socio-economic and cultural development (SARUA). With an increasingly regionalised, internationalised, and globalised world, the role and mandate of higher education extends beyond national borders; and higher education systems are expected to produce what are now known as "global professionals" and "global citizens." Graduates must not only fill vital functions in the economy but must also carry other social and civic roles and responsibilities. In fulfilling its responsibility to train its graduates, universities play a role in promoting social cohesion by developing citizens with "the ability to think critically; the ability to transcend local loyalties and to approach world problems as a 'citizen of the world'; and, finally, the ability to imagine sympathetically the predicament of another person" (Nussbaum, 2008). This goal should be pursued at levels of higher education including the institutional and regional levels.

\section{Global Citizenship, Social Responsibility, and Civic Engagement}

In reaction to the increased commercialisation of higher education at the global level, authors call for more attention to social cohesion and to the public role of higher education as an alternative force to the growing emphasis on competition, markets, and entrepreneurialism in higher education. "Global citizenship" is a term that is increasingly used in international education to address this alternative, non-commercial approach to internationalisation and many universities are in the process of integrating the concept into their internationalisation efforts. Naidoo and Jamieson (2005), for instance, state: "The forces unleashed on higher education in the present context have propelled universities to function less as institutions with social, cultural and indeed intellectual objectives and more as producers of commodities that can be sold in the international marketplace" (p. 39).

The term "global citizenship" is increasingly used to define the main outcome of international education: to educate graduates who will be able to live and work in the global society of which we are part. "The notion of global citizenship has become part of the internationalisation 
discourse in higher education around the world . .. and is increasingly the focus of doctoral research and scholarly work" (Deardorff \& Jones, 2012, p. 295).

Jorgenson and Schultz (2012) note:

It is evident that global citizenship is far from a uniform idea and, in fact, is a much contested term. There is a general consensus, however, that higher education institutions have a role to play in preparing citizens who are informed and able to participate in our complex globalised and globalizing world. Post-secondary institutions join other social institutions in working toward understanding their role in addressing social, economic, and political issues of our times. (p. I)

Two components-the social and the professional—are seen as key aspects: (a) living and working in a global society. The social requirement has been rather dominant so far, but (b) the professional one (employability) has come more to the forefront recently. As Deardorff (2009) states: "One can observe a shift in the definition of global citizenship as a concept built on a triad of knowledge, understanding, and action to one that is built on a triad of knowledge, skills, and economic competitiveness" (p. 206). This insight might be related to the increasing marketisation of higher education and its internationalisation.

Jorgenson and Schultz (20I2) note in that respect:

Globalisation has increased economic competition within and between countries, and the level of economic competition is viewed as the prime indicator of a country's well-being. Education premised upon this aspect of globalisation has a purpose of creating more economically competitive citizens who are advantaged because of particular knowledge, skills, and attitudes. (p. 4)

However, they also observe:

Criticisms of the lack of analysis of global issues, uncritical approaches to social and political structures, and failure to critically reflect on one's position relative to the rest of the world appear in several articles that articulate a vision of what education for global citizenship should and should not uphold. . . . Without critical analysis and reflection, the critics of competitive citizenry claim, the perpetuation of inequality will not be addressed, but rather seen as a legitimate impact and necessity of economic advancement and advantage. (p. 5)

Although global citizenship is a highly contested and multifaceted term, three key dimensions seem to be commonly accepted: (a) social responsibility, (b) global competence, and (c) civic engagement (Morais $\&$ Ogden, 20II). They explain: "Global citizenship is understood as a multidimensional construct that hinges on the interrelated dimensions of social responsibility, global competence, and global civic engagement" (p. 449).

Morais and Ogden (20II) understand "social responsibility" as the perceived level of interdependence with and social concern about others, about society, and about the environment. They define "global competence" as having an open mind while actively seeking to understand others' cultural norms and expectations and leveraging this knowledge to interact with, communicate with, and work effectively outside one's environment. "Global civic engagement" is understood as the demonstration of action and/or predisposition toward recognizing local, state, national, and global community issues and responding through actions such as volunteerism, political activism, and community participation (pp. 447-448).

Two of these aspects-social responsibility and civic engagementare a more explicit and central part of the mission of universities in regions like Latin America, where they are an integral part of the concept of the autonomous university. Africa also stresses these components more than other higher education systems in the world. This emphasis, as we have seen, is manifested in the role that SARUA and IUCEA play in regional cooperation and development in Southern and East Africa. At the institutional level and particularly in the curriculum construction, it finds expression in the offering of courses on development studies or global studies as compulsory or core-curriculum courses, with the goal of equipping graduates with social skills, worldviews, and perspectives that go beyond their disciplines and specialisations to enable them to operate effectively as national, regional, and global citizens.

The driving rationale for European cooperation in education and research in the context of regional unification process, next to economic competitiveness, was the desirability of creating a sense of European citizenship (de Wit, 2002, p. 89). Will we see the development of an "African citizenship" as a future rationale for regional cooperation in Southern and East Africa as well?

\section{Risks and Opportunities for Africa}

Higher education has genuine risks and challenges. Many authors acknowledge the risk for developing countries inherent in the increasingly competitive dimension of international higher education. Lesley Wilson (2013), Secretary-General of the European Universities Association (EUA), observes, for instance:

As the global pressure to develop knowledge societies accelerates, there is a risk that the gap between the developed and the develop- 
ing countries will continue to widen. Brain drain, the large-scale emigration of highly skilled human capital, is a major concern to society at large, and for the higher education and research community. In spite of attempts to promote "brain circulation," it will surely remain a major concern in the decades to come. (p. 33).

De Wit (20I3) states: “Until recently 'internationalisation' like 'international education' was predominantly a Western phenomenon, in which the developing countries played only a reactive role" (p. 6). The increasing importance of emerging and developing economies-and the related factor of a stronger higher education community in other parts of the world-alters the landscape of internationalisation.

The debate about reinventing internationalisation is stimulated by the provocative article by Uwe Brandenburg and Hans de Wit (20II), "The End of Internationalisation" which argues: (a) International educators must move away from dogmatic and idealist concepts about internationalisation; (b) Internationalisation must not be seen as an end in itself, but as a means of enhancing the quality of higher education; (c) Internationalisation must not be identified only as mobility; and (d) Research must focus more on quality and outcomes than on numbers and outputs. As a follow-up on that article, the 2012 action plan of International Association of Universities (IAU) states the need for new visions and strategies to challenge traditional views on higher education and its internationalisation.

\section{The Status of Internationalisation in African Higher Education}

The challenges and opportunities for African emerging and developing countries are to define their own roles and strategies in the internationalisation process. As Mohamedbhai (20I3) states:

Internationalisation is not new to African higher education. Indeed, it was through internationalisation that most African universities were created and developed. The majority of them were patterned on universities in countries of which they were former colonies. Most of their faculty were trained in universities in the North; the institutions with which they had the largest number of exchange programmes were located in the North, the curricula and programme structures of their degrees were similar to those in Northern universities, and all the institutions used a European language for instruction. Whether these universities were appropriate to Africa's social and economic development at the time is debatable. They were alienated from the rural areas where the majority of the population lived and where the development challenges were greatest. It has been argued that this was one of the reasons for the eventual decline of many African universities in the decades that followed. (p. I39)

Mohamedbhai then describes fruitful directions for an African approach and strategy to internationalisation:

They [institutions of higher education] need to contextualise and prioritise their internationalisation activities. Since many African countries share the same development challenges, their universities need to give preference to regional activities, regionalisation being very much a sub-set of internationalisation. Most funding and development agencies are supportive of regional collaboration among African universities. The involvement and commitment of national policy makers in this new approach to internationalisation of higher education [are] crucial. There is equally a need for dedicated and coordinated efforts regionally to support [the] internationalisation of higher education in Africa. (p. I4I)

The pursuit of regionalisation activities by governments and universities should not only be driven by economic rationales, but also by the social, political, and human development needs of their regions. Sehoole and Knight (2013) state:

In today's globalised world, which prioritises economic growth through liberalised trade and competitive market strategies, much emphasis has been placed on higher education's ability to produce graduates to serve the labour market and produce new knowledge for the knowledge economy. While these are important contributions, the role and responsibilities of higher education to address human development and social, cultural, health and governance issues should not be neglected. New knowledge produced and applied to these areas of development is crucial and should not be ignored in favour of knowledge for economic purposes. (pp. I-2)

Contrary to perspectives that see development mainly in economic terms, the conception of development in their book that examined the role of internationalisation in meeting Millennium Development Goals (MDGs), is couched in non-economic terms and is driven by the values and principles which underpin the eight MDGs.

Shabani (20I0) points out that regional and international cooperation can play a vital role in the process of knowledge generation and dissemination. Developing a meaningful and comprehensive research capacity must therefore be a core element of any university's globalisation, internationalisation, or regional strategy. But improving research capacities at African universities will require more than just additional funds. University leaders and management need a resolve and clear vision of how to use their scarce resources to develop coherent 
research agendas in partnership with other institutions in the region or overseas.

More than any other players, higher education institutions are primarily responsible for knowledge production, access, and dissemination for the benefit of their nation, regions, and the world. Kearney (2009, p. II) notes that the research conducted within academia remains a prime source of knowledge and innovation at national, regional, and international levels. Hayward (2010) argues that strong graduate programmes provide the critical nexus between research and teaching and expand the opportunities for graduate research. He proposes the establishment of regional models with help from governments, donor organisations, and foundations. The recognition that graduate programmes are a major avenue to enhancing the region's intelligentsia and knowledge-creation capability has sparked the growth of regional training centres. Hayward further argues that a regional approach will probably be most effective for the development of research and graduate training capacities. The commitment of national governments, among others, is essential in developing policy frameworks and in financing the creation of environments in which knowledge can thrive.

\section{New Ground that African Institutions Must Break}

Higher education in Africa and other emerging and developing regions faces many challenges, but these very challenges are opportunities to develop new innovative approaches and strategies in their international dimensions. De Wit (20I3, p. 7) provocatively states that higher education in Africa might first have to "de-internationalize," moving away from its past dominance by Western structures, concepts, and learning models to develop its own style of internationalisation. The colonial importance of Western systems, structures, and cultures of higher education, the presence of an older faculty whose members were predominantly trained in Europe and North America, and the ongoing brain drain of African students to these continents, have created an imported higher education environment, which has created severe obstacles to an independent higher education and its internationalisation in Africa. Stronger emphasis on regional and South-South cooperation is essential in achieving this kind of educational independence. Social responsibility and civic engagement, building on their foundation in African society and higher education, can be key innovative drivers for the internationalisation of higher education in Africa.

There is, however, a challenge to which institutions and, in particular, African scholars must respond in their quest to building capacity and knowledge production. Zeleza (2012) notes that the hegemony of Western perspectives from the developed world is of direct relevance to the process of internationalisation. He argues that "internationalisation that is not grounded and nourished by African epistemic roots is likely to reproduce and reinforce the production of mimic knowledges; pale copies of Western knowledge's of little value to Africa and no consequence to world scholarship" (p. 20). In this regard, African scholars are challenged to produce knowledge that is relevant to their own development context and to explore avenues by which to disseminate this knowledge by and to students and scholars worldwide. This critique and view of the need to produce knowledge relevant to the African context reinforces de Wit's challenge for Africa to deinternationalize from its Western models before developing its own, indigenously rooted internationalisation policies and practices. Although one can say that both Zeleza and de Wit oversimplify the possibilities for a more autonomous African internationalisation of higher education, their arguments can be read as a call for a less re/active approach to it.

Precedents set by SADC and its predecessor organisations in championing the anti-colonial and anti-imperial struggles in Southern Africa, the similar role played by IUCEA in East Africa, and the development role that SARUA played in research and knowledge production offer important lessons for championing alternative institutions for sociopolitical, economic, and knowledge production for advancement of their sub-regions. Serious examination of the histories of the evolution of these organisations and how they have gone about their work can offer models that can be adapted for developing alternative paradigms for regionalisation and internationalisation.

\section{Pan-African Regional Initiatives}

Apart from regionalisation initiatives at the sub-regional level are PanAfrican regional initiatives aimed at promoting regionalization as documented in the Second Decade of Education in Africa (AU, 2008). The African Union Commission (AUC) views regional integration as a key and immediate step toward integrating African countries into the global economy through convergence of the continent's higher education system.

The African Union (AU) is currently developing a strategy for harmonising higher education programmes and, at its core, is the development of criteria for harmonising qualifications across countries. The Pan-African University (PAU), with its centres spread across Africa, has been established by AU as one way of enhancing collaboration and cooperation among African countries in targeted areas within special- 
ised regional centres to enhance quality, research, and postgraduate education (AU, 2008).

Such initiatives point to the fact that Africa's challenge in the area of regionalisation and internationalisation, like many other challenges, is not the absence of initiatives, but of strategic planning, coordination, and implementation. It is clear that many national, regional, and continental initiatives and programmes have been launched to promote the benefits and to minimise the risks of internationalisation, but they have been hampered by poor coordination, inadequate resources, insufficient institutional capacities, and lack of strategic planning (Zeleza, 20I2; Jowi, 20I2; Teferra \& Knight, 2008).

There is a need to develop systems that are more comprehensive, better integrated, and more robust. Achieving such goals necessitates greater regional cooperation by creating regional standards, benchmarks, policies, and regulations. The key issues and initiatives would need to include the creation of credit transfer systems; the establishment and coordination of national and regional accreditation and quality control mechanisms; the promotion of regional research consortia and networks; the mobilisation of the industrial and philanthropic sectors for funding support; increased investment in research; deeper higher education participation in research and development; the strengthening of graduate programmes and academic staff development; and the improvement of facilities.

\section{Conclusion}

In this article, we have positioned the debate of the relationship between regionalisation, internationalisation, and globalisation in African regional and sub-regional contexts. The article has further shown the phenomenon of the evolution of regionalisation and its relationship to and interaction with internationalisation and globalisation. Regionalisation and internationalisation are closely related, with the former appearing as a subset of the latter. Both predate globalisation as a driving phenomenon. Their characteristics change under the influence of globalisation. Both internationalisation and globalisation need regional organisations to spur advancement as demonstrated by the closely matched model of the evolution of regional economic trade blocs and their links to the evolution of the global trade regime. Similarly, analysis of international academic mobility shows that it follows regional data about the same model. As such, a strong case has been made to consider the regional level as the basis for considering effective development in several areas, including higher education, for the African continent.
In the current global knowledge society, higher education plays an increasingly central role. That role is complex. Higher education both reacts to internationalisation efforts and acts upon those forces through diverse internationalisation strategies. In a region like Africa, higher education is also closely related to development, while social responsibility and civic engagement are key drivers for the sector. We argue that the internationalisation of higher education in Africa cannot simply copy what is happening in other parts of the worldin particular the traditional models imported from Europe and North America-but must build on its own roots, strengths, and opportunities. Enhancement of regional and sub-regional cooperation in African higher education is one requirement for the further development and quality improvement of its higher education and of the contribution of higher education to the society and economy in the continent. The existence of higher education regional bodies and the role of national organisations focusing on internationalisation can serve as vehicles for driving internationalisation forward.

\section{References}

Altbach, P. (2006). Globalisation and the university: Realities in an unequal world. In P. G. Altbach \& J. J. F. Forest (Eds.), International handbook of higher education. Dordrecht, The Netherlands: Springer.

AU. African Union. (2008). Second decade of education for Africa: (20062015). Addis Ababa, AU.

Brandenburg, U., \& De Wit, H. (2oII, Winter). The end of internationalisation. In International Higher Education, No. 62, I5-I6.

Crush, J., \& Pendleton, W. (2007). Mapping hostilities: The geography of xenophobia in Southern Africa. South African Geographical Journal, 89(I): 64-82.

De Wit, H. (2002). Internationalisation of higher education in the United States of America and Europe: A historical, comparative, and conceptual analysis. Westport, Conn., USA: Greenwood Press.

De Wit, H. (20I3). Reconsidering the concept of internationalisation. In International Higher Education, No. 70, 5-7.

Deardorff, D. K. (2009). Understanding the challenges of assessing global citizenship. In L. Ross (Ed.), The handbook of practice and research in study abroad: Higher education and the quest for global citizenship (pp. 246-264). New York: Routledge/AACU.

Deardorff, D. K., \& Jones, E. (20I2). Intercultural competence: An emerging focus in international higher education. In D. K. Deardorff, H. de Wit, J. D. Heyl, \& T. Adams (Eds.). The SAGE handbook 
of international higher education (pp. 283-303). Thousand Oaks, California, USA: SAGE.

East African Legislative Assembly. (2009). Inter-University Council of East Africa Act 2008. Retrieved February I7, 2014, from http://www. google.co.za/url?sa.

Egron-Polak, E. (20I3). Internationalisation: A gateway to a new inclusive global higher education space. In H. de Wit, F. Hunter, L. Johnson, \& H.-G. van Liempd (Eds.), Possible futures: The next 25 years of the internationalisation of higher education (pp. 86-9I). Amsterdam: European Association for International Education.

European Commission. European higher education in the world. Communication from the Commission to the European Parliament, the Council, the European Economic and Social Committee and the Committee of the Regions. Brussels, II.7.20I3, COM(2013) 499 final. Retrieved May 28, 20I4, http://eur-lex.europa.eu/LexUriServ/LexUriServ.do?uri=COM:2013:0499:FIN:en:PDF.

Evans, M. (1984). The front-line states, South Africa, and Southern Africa security: Military prospects and perspectives. University of Zimbabwe Department of History. Retrieved on March II, 20I4, from http:// archive.lib.msu.edu/.

Hayward, F. (2010). Graduate education in Sub-Saharan Africa. In D. Teferra \& H. Greijn (Eds.). Higher education and globalisation. Maastricht, The Netherlands: Maastricht University Centre for International Cooperation in Academic Development (MUNDO).

IAU. International Association of Universities. (2OI2). affirming academic values in internationalization of higher education: A call for action. IAU, April 20I2. Retrieved on May 25, 20I4, from http:// www.iau-aiu.net/sites/all/files/Affirming_Academic_Values_in_ Internationalization_of_Higher_Education.pdf.

Jorgenson, Sh., \& Shultz, L. (20I2). Global citizenship education (GCE) in post-secondary institutions: What is protected and what is hidden under the umbrella of GCE? Journal of Global Citizenship Q Equity Education, 2(I): I-22. Special edition. Retrieved on May I4, 20I4, from http://journals.sfu.ca/igcee/index.php/igcee/issue/ view/4.

Jowi, J. (2OI2). Africa responds to internationalisation: Redefining the terms of engagement between scholars worldwide. SARUA Leadership Dialogue Series, 4(2), 49-6I.

Kumala, D. B. (2006). The achievements and challenges of the New East African Community Cooperation. Lecture presented at the Business School, University of Hall Business School, May 3, 2006. Retrieved on February I8, 20I4, from http://www2.hull.ac.uk/hubs/pdf/ memorandum58.pdf.

Kearney, M.-L. (2009). Higher education, research, and innovation: Charting the course of the changing dynamics of the knowledge society. In V. L. Meek, U. Teichler, \& M.-L. Kearney (Eds.). Higher education research and innovations: Changing dynamics (pp. 7-24). Paris, France: UNESCO.

Knight, J. (2008). Higher education in turmoil: The changing world of internationalisation. Rotterdam, The Netherlands: Sense Publishers.

Knight, J. (2013). Toward African higher education regionalisation and harmonisation: Functional, organisational, and political approaches. In A. W. Wiseman \& C. C. Wolhuter (Eds.). The development of higher education in Africa: Prospects and challenges (pp. 347-373). Vol. 2I of International Perspectives on Education and Society. London: Emerald Group Publishing.

Kornegay F. (2006) Pan-African citizenship and identity formation in Southern Africa: An overview of problems, prospects and possibilities. Research report No 107. Johannesburg, South Africa: Centre for Policy Studies.

Kotecha, P. (20I2) Engaging universities in the regional integration project in Southern Africa. SARUA Leadership Dialogue Series, $4(2): \mathrm{I}-3$.

Mhlanga, E. (2012). Regionalisation and its impact on quality assurance in higher education. Special Issue. Creative Education, 3, 1079-1086.

Mohamedbhai, G. (2013). Internationalisation of African higher education: A different approach? In H. de Wit, F. Hunter, L. Johnson, \& H.-G. van Liempd (Eds.), Possible futures: The next 25 years of the internationalisation of higher education (pp. I38-I4I). Amsterdam, The Netherlands: European Association for International Education.

Morais, D., \& Ogden, A. (20II, November). Initial development and validation of the global citizenship scale. Journal of Studies in International Education, 15(5), 445-466.

Naidoo, R., \& Jamieson, I. (2005). Knowledge in the marketplace: The global commodification of teaching and learning in higher education. In P. Ninnes \& M. Hellsten (Eds.). Internationalizing higher education: Critical explorations of pedagogy and policy (pp. 37ff.). Hong Kong: Comparative Education Research Centre, the University of Hong Kong/Springer.

Nussbaum, M. (2008). Education for profit, education for freedom. First annual Seymour J. Fox Memorial Lecture, The Hebrew University of Jerusalem, December I6, 2007, and Opening Plenary Address, 
Association of American Colleges and Universities, Washington, DC, January 24, 2008.

SARUA, 20I2). SARUA Leadership Dialogue Series, 4(2), iv.

Scott, P. (2005). The global dimension: Internationalising higher education. In B. Khem \& H. de Wit (Eds.), Internationalisation in higher education: European responses to the global perspective (pp. 8-22). Amsterdam, The Netherlands: European Association for International Education and the European Higher Education Society.

Sehoole, C., \& Knight, J. (2013). Internationalisation of African Higher Education: Toward achieving the MDGs. Rotterdam, The Netherlands: Sense Publishers.

Shabani, J (20I0). Regional and international academic and research cooperation in Africa. In D. Teferra \& H. Greijn (Eds.), Higher education and globalization: Challenges, threats, and opportunities for Africa. Maastricht, The Netherlands: Maastricht University Centre for International Cooperation in Academic Development (MUNDO).

Teferra, D., \& Knight, J. (Eds.). (2008). Higher education in Africa: The international dimension. Accra, Ghana: Association of African Universities/Boston, Massachusetts, USA: Center for International Higher Education.

TRALAC. Trade Law Centre for Southern Africa. (20II). Monitoring regional integration in Southern Africa: 2010 yearbook. Stellenbosch, South Africa: TRALAC and Konrad-Adenauer-Stiftung.

Tsuruta, Y. (2003). The globalisation, regionalisation, and internationalisation of higher education with special reference to Japan: A theoretical consideration. A paper presented at the British Educational Research Association annual conference, Heriot-Watt University, Edinburgh, September II-I3, 2003. Retrieved on February I8, 20I4, from http://www.leeds.ac.uk/educol/documents/00003432.htm.

UNESCO. United Nations Educational, Scientific and Cultural Organisation. (20I2). New patterns in student mobility in the Southern Africa Development Community. UIS Information Bulletin, 7. Retrieved on May 23, 20I4, from http://www.uis.unesco.org/FactSheets/Documents/ib7-student-mobility-2or2-en.pdf.

Van Vught, F., van der Wende, M., \& Westerheijden, D. (2002). Globalisation and internationalisation: Policy agendas compared. In J. Enders \& O. Fulton (Eds.), Higher education in a globalising world: International trends and mutual observations. A festschrift in honor of Ulrich Teichler (pp. I03-I20). Dordrecht, The Netherlands: Kluwer Academic Publishers.

Wilson, L. (2013). The internationalisation of higher education and research: European policies and institutional strategies. In H. de Wit, F. Hunter, L. Johnson, \& H.-G. van Liempd (Eds.), Possible futures: The next 25 years of the internationalisation of higher education (pp. 28-33). Amsterdam, The Netherlands: European Association for International Education.

Zeleza, P. T. (20I2). Internationalisation in higher education: Opportunities and challenges for the knowledge project in the global south. SARUA Leadership Dialogue Series, 4(2), 4-27. 